\title{
The Journey Towards the Self: A Study of Amitav Ghosh's The Hungry Tide in an Ecocritical Perspective
}

\author{
A Aravinth Raja \\ Temporary Assistant Professor of English \\ Manonmaniam Sundaranar University \\ Tamil Nadu, India \\ aravinthaar@gmail.com
}

Abstract

This paper attempts to study The Hungry Tide by Amitav Ghosh from an ecocritical perspective. The researcher identifies the journey of the characters in the novel towards nature as a metaphorical symbol to the journey in discovering the self. The conflict between the people and the environment is the only obstacle during the journey of the characters in the novel. The characters experience the conflict between the environment and people through observation and at the same time, self-realisation. This paper also identifies the author's concern for nature through the fictional characters in the novel Piyali Roy, a cetologist and Fokir, a local fisherman. In an ecocritical perspective, this paper sees the disturbances that the nature experience as a harm towards nature and its progression.

Keywords: Ecocriticism, Environment, Sunderbans, Nature, Self.

Ecocriticism is a branch of literary studies that emerged during the late of the twentieth century with the publication of the essay "Literature and Ecology: An Experiment in colonialism", where the author William Rueckert coined this new term "ecocriticism". It is defined as "to find the grounds upon which the two communities - the human, the natural- 
can coexist, cooperate, and flourish in the biosphere" (107). Ecocriticism has not become popular for a very long time and it expanded as a widely used cultural and literary theory after the formation of the Association for the Study of Literature and Environment (ASLE) and also the publication of The Ecocriticism Reader: Landmark in literary ecology.

Amitav Ghosh in his 2004 novel The Hungry Tide has shown a great concern for the environment, especially to the Sundarbans. Sundarbans, according to Ghosh means a "beautiful forest" (8) as he describes in the novel. A forest is described beautifully despite having wild creatures which can be harmful to the human society shows the ardent love for the environment by Ghosh. The concern towards the environment is seen throughout the novel, where he uses two main characters named Piyali Roy and Fokir to express it. The novel can also be studied as a journey towards the Self because of the journey of the characters towards Sundarbans. The narrator of the novel, Kanai comes to Sundarbans to collect the diary of a man, who died in the Morichabi massacre, an event of great historical importance. Meanwhile, Piya comes to Sundarbans from abroad to study about a particular species of dolphin which is seen many in number in the rivers of Sundarbans. These journeys can serve as a metaphor for the journey towards the Self.

Kanai comes to discover the events that happened in the Sundarbans by reading the diary that Nirmal has written for him. Through this, we find out that Nirmal's journey towards the Sundarbans is also a journey towards the self because he comes to Sundarbans to get away from his trauma. Sundarbans, being a major setting of the novel, the author has tried to make the place as a central image, where every character comes in searching for their Self. Piya's passion for the study of Irrawaddy dolphin has shown the way to her for Sundarbans, where she feels safe and secure. She also finds comfort with the place because of her tragic past life which she shares during the course of the novel. She shows patience while searching for the dolphin by which the author has tried to show the importance of patience while 
discovering the Self. She feels secure in the company of Fokir, a fisherman from Lusibari Island even during the night time but she does not feel safe and secure when she was introduced to the boat owner Mej-da by the forest officials. In this aspect, the journey of the characters can also be considered as a journey towards nature or environment, thereby the author tries also to emphasise the concern towards the environment. The author stresses the importance of seeking a relationship with nature through Piya. Nature can provide the comfort and security which the industrial society could not and at the same time, the journey towards nature can also make to discover the self.

The concern for nature in the text is also evident from the minor incidents in the novel. In Lusibari, people make their habitats by cutting the trees. When Kanai came to Lusibari in 1970, the island was full of trees, birds, and animals. But the situation is not the same when he visits for the second time. He describes Lusibari when he came for the second time as "It was clear at a glance that the area around the compound was among the most heavily trafficked in the whole island. Clusters of huts, houses, stalls, sweetshops and the like had grown up around the compound" (38). Humans have also destroyed the aquatic wildlife in recent years with excessive fishing, the spilling of diesel into water bodies, the use of motorboats in the river, and letting sewages from industries directly into the water bodies. The use of diesel motorboats in the water bodies can be a threat to the aquatic life. The novel is also an attack on the state and its 'hegemonic' attitude. The Forest department uses diesel motorboats for taking tourists into the Sundarbans, which is a satire against the state for its hegemonic practices. In The Hungry Tide, Mej-da uses a diesel steamer which due to some leakages in the engine, spills diesel fuel into the water bodies which in turn affect the environment and aquatic wildlife. The death rate of the animals, trees, or any other living creatures is not seen serious as the death rate of that of humans. Once, during the journey of the search of dolphin Piya sees a carcass of an Irrawaddy dolphin, that too a newborn calf. 
Inspecting the wound, she finds out that it was hit by a motorboat which she expresses pathetically as "injury suggested that the dolphin had been hit by the propeller of a fastmoving motorboat" (346). The degradation of aquatic life and forest life in and around the islands are discussed in the text with a vision of making the readers more concern about the environment in which they live. The text also shows the inextricability of human life and nature.

In the text, Dolphins are considered as the messengers of Bon Bibi, whom they worship in Sundarbans. However, the practices of the officials there lead way to the extinction of these dolphins. Here, the author stresses the harm done by human beings to nature. The human practices during these years have made only harm to the other living creatures, especially in Sundarbans. Once, when Piya is set out in the river, she prepares herself taking her binoculars, rangefinder, and other equipment to identify the Irrawaddy dolphins among other dolphins in the river. She wonders about not having sight of a single dolphin at the same place where nineteenth-century zoologists found many dolphins.

That these waters had once contained a large number of dolphins was known beyond a doubt. Several nineteenth-century zoologists had testified to it. The 'discoverer' of the Gangetic dolphin, William Roxburgh, had said explicitly that the freshwater dolphins of the Ganges delighted in the "labyrinth of rivers, and creeks to the South and South-East of Calcutta'. This was exactly where she was and yet, after hours of careful surveillance she had still to spot her first dolphin (42).

The text also shows how the aquatic creatures are seen as a commodity in the global context. Piya herself has witnessed the killing of dolphins in Cambodia, where she lived once. Dolphins are killed to make its fat as oil, which can later serve as a fuel for engines. Piya's words describe the plightful condition of these dolphins as "These dolphins were hunted with rifles and explosives and their carcasses were hung up in the sun so that their fat 
would drip into buckets. This oil was then used to run boats and motorcycles" (306).

Dolphins are seen much as a commodity than a living being. The text shows much concern for the dolphins, thereby the text shows itself as a literature having concern towards nature, making the text ecocritical.

Dolphins are not the only creatures that are shown much concern in the text. Other creatures in the wildlife, in the case of Sundarbans tigers, are also shown concern. Tigers are seen worldwide as creatures which must be killed before it kills someone. This notion is expressed in The Hungry Tide also. In the text, a character named Sir Daniel Mackinnon Hamilton is portrayed as a villain against nature. When he decided to settle in Sundarban islands, he wanted to make these islands a place for living. For this purpose, he rewards people who kill tigers, crocodiles, and snakes. The major economic asset that he rewards is a piece of land. Once, when Horen's uncle Bolai kills a tiger when he was out for fishing and S'Daniel rewards him two bighas of land in Lusibari.

In the chapter "A Killing", a tiger is set to fire, the cruellest thing a man can do to an animal. The tiger came to the island hearing the sound of a buffalo giving birth to a calf. It had already killed two people on the island and now it eyed on the cattle in the island. The people caught hold of the tiger with their fishing nets. Fires have been lit on bamboo sticks to set the tiger on fire. On seeing this, Piya could not tolerate the act, she shouted to Kanai to ask them not to do such thing to an animal. When Kanai says it has killed two people and any number of cows and goats, Piya says "you can't take revenge on an animal" (294). Fokir is also involved in the act, helping a man sharpen his bamboo pole. Piya shockingly inquires Fokir why he is involving in such an act. The inhumane attitude of Fokir towards tiger can be seen when replies "when a tiger comes into a human settlement, it's because it wants to die" (295). The text shows the mentality of people towards nature and animals. People's 
selfishness is seen clearly from the act of killing tigers, thereby making the place for humans to live.

The text is very much concerned about nature and its offsprings. The characters in the text go into journeys towards nature, some as a purpose and some seeking comfort. The journeys rediscover their own self and they find solace with nature as what the romantic poets did. The text is very much ecocritical in nature under the definitions of the ecocritics. 


\section{Works Cited}

Ghosh, Amitav. The Hungry Tide. HarperCollins Publishers, 2013. Print.

Rueckert, William. "Literature and Ecology: An Experiment in Ecocriticism." The

Ecocriticism Reader: Landmarks in Literary Ecology, edited by Cheryll Glotfelty and Harold Fromm, University of Georgia Press, 1996, pp. 107-108. 